\title{
Pulmonary heart disease in Ibadan
}

\author{
E. O. SOF OWOR A \\ University College Hospital, Ibadan, Nigeria
}

\begin{abstract}
Pulmonary heart disease is encountered and is not uncommon in the tropics. The incidence of the chronic form is expected to increase, while the causes of the acute form may be different from those in temperate countries and so require different prophylactic measures.
\end{abstract}

There is an extensive literature on various disorders of the cardiovascular system in the African (Davies, 1948 ; Abrahams, 1959; Brock and Gordon, 1959 ; Higginson, Isaacson, and Simson, 1960 ; Phillips and Burch, 1960). There is, however, little reference to cor pulmonale defined as right-sided heart disease secondary to disease of the lungs or pulmonary vessels. This no doubt stems from a dearth of information on the occurrence and prevalence of respiratory diseases in the tropics, where respiratory disease has been almost synonymous with pulmonary tuberculosis. Further, it has been conjectured that the warm climate in the tropics, minimal air pollution, and, possibly, differences in smoking habits are all responsible for the apparently lower prevalence of chronic respiratory diseases such as chronic bronchitis compared with temperate countries.

The present communication is a study of pulmonary heart disease or cor pulmonale as seen in Ibadan over a 33-month period (October 1966 to June 1969). The bias introduced into such a hospital sample is that common to similar studies. Pulmonary heart disease is defined here as rightsided heart disease manifesting as congestive heart failure or right ventricular hypertrophy or both, secondary to disease of the lungs or pulmonary vessels. The ways in which the lung can adversely affect the heart are principally two-fold:

(a) pulmonary vascular obstruction, obliteration or reduction as occurs in:

(1) diffuse pulmonary fibrosis (e.g., sarcoidosis, pneumonociosis such as asbestosis, silicosis, Hamman-Rich syndrome);

(2) obstructive vascular disease (e.g., recurrent pulmonary embolism, collagen disorders, schistosomiasis) ; (b) disorders causing alveolar hypoventilation :

(1) disorders of the chest bellows such as neuromuscular diseases (poliomyelitis); chest deformities (kyphoscoliosis); extreme obesity ;

(2) diseases with chronic obstructive airwaysemphysema, chronic bronchitis; asthma ;

(3) diminished activity of respiratory centre.

Although the above classification gives the impression that pulmonary heart disease is a chronic disorder, this is not so. Acute pulmonary heart failure following on pulmonary embolism is one of the commoner and most lethal forms of pulmonary disease seen at necropsy in any general medical hospital population.

\section{CHRONIC COR PULMONALE}

During the 33-month period at the University College Hospital, Ibadan (1966 to 1969), 54 cases were diagnosed as chronic cor pulmonale. The criteria used for right ventricular hypertrophy included prominent papillary muscles, thickness of the right ventricle at the outflow tract exceeding $6 \mathrm{~mm}$, and atheromatous plaques on the intima of the pulmonary trunk. There was also evidence of pulmonary vascular sclerosis on histological examination in all the cases. The ventricles were not detached and weighed separately but all the hearts were examined by a senior pathologist. The material has been analysed with respect to age, sex, clinical features, and associated diseases.

AGE/SEX DISTRIBUTION Table I shows the age and sex distribution of the 54 patients studied. There were 36 males and 18 females. Chronic cor pulmonale appears commonest over the age of 40 years. The males were more affected than females with a ratio of about $3: 1$. 
T A B L E I

CHRONIC COR PULMONALE: AGE/SEX DISTRIBUTION

\begin{tabular}{c|c|c}
\hline Age (yr) & Male & Female \\
\hline Under 30 & 1 & 3 \\
$30-39$ & 4 & 2 \\
$40-49$ & 9 & 1 \\
$50-59$ & 5 & 6 \\
$60+$ & 17 & 6 \\
\hline Total & 36 & 18 \\
\hline
\end{tabular}

CLINICAL FeATURES The usual clinical features of cough, dyspnoea, cyanosis, clubbing of fingers and toes, oedema of limbs with enlarged liver and raised jugular venous pressure were encountered. These clinical features were not different from those in the Caucasians. The usual assumption that cyanosis is difficult to observe in the African is not absolutely correct although mild cases may present difficulty to the inexperienced eye. In fact, central cyanosis is best seen under the tongue in good light.

T A B L E I I

CHRONIC COR PULMONALE: ASSOCIATED DISEASE

\begin{tabular}{l|c|c}
\hline & $\begin{array}{c}1966 / 9 \\
\text { (Present study) } \\
\text { University College } \\
\text { Hospital } \\
\text { Ibadan }\end{array}$ & $\begin{array}{c}1963 / 5 \\
\text { (Okuwobi, 1967) } \\
\text { Lagos University } \\
\text { Teaching } \\
\text { Hospital }\end{array}$ \\
\hline \begin{tabular}{c|c} 
Total no. of cases \\
Obstructive airways
\end{tabular} & 54 \\
Tuberculosis & 32 & 19 \\
Chest deformity & 15 & - \\
Bryphoscoliosis) & 1 & - \\
Bulmchiectasis & 4 & - \\
(Hb SC disease) & 2 & 1 \\
Unknown (? sarcoidosis) & - & \\
\hline
\end{tabular}

ASSOCIATED DISEASES Table II shows the diseases found commonly to be associated with chronic cor pulmonale in this series. This is compared with figures from a teaching hospital in Lagosa distance of about 90 miles from Ibadan (Okuwobi, 1967).

Diseases which have obstructive airwayschronic bronchitis, emphysema, bronchial asthma - form by far the commonest causes of chronic cor pulmonale in these two series, closely followed by pulmonary tuberculosis.

INVESTIGATIONS Chest radiographs, ECGs, sputum examinations, blood counts, and haemoglobin genotypes were carried out in all patients, 10 of whom also had pulmonary function tests. The results showed in general reduced $\mathrm{Po}_{2}$ and increased $\mathrm{PCO}_{2}$ as expected.

\section{ACUTE COR PULMONALE}

By far the commonest cause of acute cor pulmonale in a general medical ward is pulmonary embolism. Clinically, this is manifested by one or more of the following features in a convalescent postoperative or postpartum patient: unexplained dyspnoea, sudden chest pain, haemoptysis, collapse, or tachycardia. Resistant oedema in a cardiac patient, cyanosis, and apprehension are occasionally presenting features.

In the period under study (1966-9), 49 cases were diagnosed clinically and at necropsy. When compared with chronic cor pulmonale, the older age group (over 40) was more affected and males were affected more than females (Tables I and III). Cardiac and other debilitating medical states were the commonest associated conditions (Table IV). Improved anaesthesia, pre- and postoperative care, and early mobilization have greatly reduced the numbers following surgery. In spite of increased surgical admissions to the University College Hospital due to the Nigerian civil war during the period under study, there were surprisingly few cases of pulmonary emboli.

T A B L E I I I

ACUTE COR PULMONALE: AGE/SEX DISTRIBUTION

\begin{tabular}{c|c|c|c|c}
\hline & \multicolumn{2}{|c|}{$\begin{array}{c}\text { Present Study } \\
1966-9\end{array}$} & \multicolumn{2}{|c}{$\begin{array}{c}\text { 1959-64 } \\
\text { Nwokolo and Ikoku (1966) } \\
\text { University College } \\
\text { Hospital }\end{array}$} \\
\cline { 2 - 5 } Age (yr) & Male & Female & Male & Female \\
\hline $0-19$ & 4 & 1 & 4 & 1 \\
$20-39$ & 4 & 16 & 9 & 17 \\
$40-59$ & 7 & 8 & 10 & 8 \\
$60+$ & 8 & 1 & 9 & 0 \\
\hline
\end{tabular}

T A B LE I V

ACUTE COR PULMONALE: ASSOCIATED DISEASES

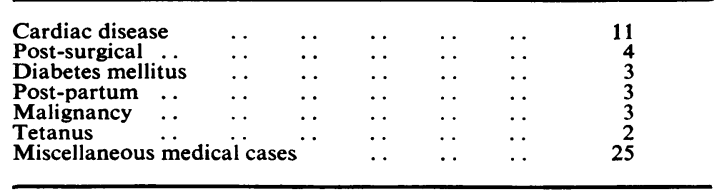

The mortality in the present series was $83.7 \%$. Although this is a potentially curable disorder surgically and prevention of further attacks is highly successful in special centres, these therapeutic measures can be introduced only if a correct diagnosis is made, and unfortunately this is notoriously difficult. As chest radiographs may 
not be helpful and ECGs, lactic dehydrogenase estimation, pulmonary angiography, and lung scanning are not universally available, a high index of suspicion is desirable.

In the tropics, patients with abnormal haemoglobin need particular observation as they are especially prone to thrombosis (Edington, 1955; Moser and Shea, 1957 ; Woodruff, 1961 ; Nwokolo and Ikoku, 1966).

Although attention has so far been directed to thromboembolism as a source of acute cor pulmonale, other types of emboli have been seen, for example, marrow emboli in sickle-cell crisis ; tumour emboli in malignant trophoblastic disease ; and amniotic and fat emboli.

\section{DISCUSSION}

Over the last few years at the University College Hospital, Ibadan, there has been an upward trend in the percentage of all cases of cardiac disease attributable to cor pulmonale as compared with the series of Lauckner, Rankin, and Adi (1961) and Ikeme and Parry (1966) shown in Table V. In Lagos, cor pulmonale forms the second commonest cause of heart failure (Okuwobi, 1967). This rise is due to an increased awareness of the presence of the condition and the fact that every chronic cough is no longer regarded as due to tuberculosis. Furthermore, people tend to seek medical attention earlier because they are aware of the facilities and services of a chest clinic.

T A B L E V

FREQUENCY OF COR PULMONALE IN CARDIAC CASES STUDIED

\begin{tabular}{|c|c|c|c|c|}
\hline & \multicolumn{3}{|c|}{$\begin{array}{c}\text { University College } \\
\text { Hospital } \\
\text { Ibadan }\end{array}$} & \multirow{2}{*}{$\begin{array}{c}\begin{array}{c}\text { University Teaching } \\
\text { Hospital } \\
\text { Lagos }\end{array} \\
1963-5 \\
\begin{array}{c}\text { (Okuwobi, } \\
1967)\end{array}\end{array}$} \\
\hline & $\begin{array}{c}1958 \\
\text { (Lauckner } \\
\text { et al., } \\
\text { 1961) }\end{array}$ & $\begin{array}{c}1965 \\
\text { (Ikeme } \\
\text { and } \\
\text { Parry, } \\
\text { 1966) }\end{array}$ & $\begin{array}{l}\text { 1966-9 } \\
\text { (Present } \\
\text { review) }\end{array}$ & \\
\hline $\begin{array}{l}\text { Total } \\
\text { cardiac }\end{array}$ & 139 & 151 & 245 & 157 \\
\hline $\begin{array}{l}\text { cases } \\
\text { monale }\end{array}$ & $1 \%$ & $9 \%$ & $23.9 \%$ & $21 \%$ \\
\hline
\end{tabular}

The age-sex distribution observed is in keeping with that of temperate countries. The younger age groups suffer from the end result of badly managed pulmonary tuberculosis and bronchiectasis while the older age groups suffer from chronic bronchitis and emphysema.
Diseases with obstructive airways form by far the commonest cause of chronic cor pulmonale in temperate countries. In contrast to our expectation, this is the finding in the two series from Nigeria (Table II). These conditions are presumed to be uncommon in the tropics because of a relative absence of significant aetiological factors. The prevalence of chronic obstructive airways has not been determined in the tropics although evidence from necropsy studies by Stuart and Hayes (1963) in Jamaica showed that 14\% of all cases of right-sided heart failure were due to chronic lung disease. Hayes and Summerell (1963) thought that emphysema in Jamaica was as prevalent as in a temperate environment. The author has also observed that in rural communities in Igboora in Western Nigeria chronic respiratory diseases are not uncommon (Sofowora, in preparation).

The figure for tuberculosis may be an underestimate because most cases, in both Lagos and Ibadan, go to the Government chest clinics which have been operating for the last 10 years. Tuberculosis, fast disappearing in the developed countries, is still rampant in the tropics, and inadequate treatment due to a high default rate and an insufficiency of drugs often leads to fibrosis which then predisposes to cor pulmonale. It is still a great problem in Nigeria and the resistant variety is increasing due to poor management. Unless measures are taken to improve the overall management of tuberculosis, the contribution of this disease to chronic cor pulmonale will either remain the same or increase.

Chest deformity, including kyphoscoliosis, due to tuberculosis is also seen. Bronchiestasis is common and tends to progress to cor pulmonale at an early age because of improper management early on in the disease. Other aetiological factors which have been seen in the University College Hospital infrequently are schistosoma affection of the lungs and recurrent intravascular sickling from microemboli in haemoglobin SS and SC disease.

Chronic bronchitis and emphysema form the highest percentage of our cases, and with increasing industrialization, atmospheric pollution, and smoking habits the frequency and severity will probably increase.

Further studies into the role of abnormal haemoglobin in the pathogenesis of pulmonary hypertension and eventual cor pulmonale are in progess. While the SS (homozygous) patient group tends to die at an early age, the AS and SC patients tend to live a normal life span. Intravascular sickling, leading eventually to vascular 
narrowing and hypertension have been well documented (Moser and Shea, 1957; Olazábal et al., 1968). It seems, therefore, that with these other aetiological factors prevalent in the tropics, the frequency of chronic cor pulmonale will closely approach and, in due course, may even exceed that in temperate countries. The acute variety is possibly commoner than in the temperate countries because of the added effects of abnormal haemoglobins. As therapy and prophylaxis are far ahead of diagnosis in this latter variety, a high index of suspicion is called for. There is an urgent need for the determination of the extent of these disorders, especially the chronic variety. We may find that measures necessary to reduce the incidence and severity of these conditions in the tropics may be different from those currently being applied in temperate countries.

I wish to express my gratitude to Dr. T. I. Francis, Dr. R. Carlisle, Professors T. O. Ogunlesi, B. K. Adadevoh, and A. O. Williams, for various suggestions in the preparation of this paper, and to Mrs. O. Olunloyo for secretarial assistance.

\section{REFERENCES}

Abrahams, D. G. (1959). An unusual form of heart-diseas: in West Africa. Its relation to endomyocardial fibrosis. Lancet, 2, 111.

Brock, J. F., and Gordon, H. (1959). Ischaemic heart disease in African populations. Postgrad. med. J., 35, 223.
Davies, J. N. P. (1948). Endomyocardial fibrosis in Africans. E. Afr. med. J., 25, 10.

Edington, G. M. (1955). The pathology of sickle-cell disease in West Africa. Trans. roy. Soc. trop. Med. Hyg., 49, 253.

Hayes, J. A., and Summerell, J. (1963). Emphysema in Jdmaica. W. Indian. med. J., 12, 34.

Higginson, J., Isaacson, C., and Simson, I. (1960). The pathology of cryptogenic heart disease. Arch. Path., 70, 497.

Ikeme, A. C., and Parry, E. H. O. (1966). Cardiovascular Disease in Nigeria, p. 81. Ibadan University Press.

Lauckner, J. R., Rankin, A. M., and Adi, F. C. (1961). Analysis of medical admissions to University College Hospital, Ibadan, 1958. W. Afr. med. J., 10, 3.

Moser, K. M., and Shea, J. G. (1957). The relationship between pulmonary infarction, cor pulmonale and the sickle states. Amer. J. Med., 22, 561.

Nwokolo, C., and Ikoku, N. (1967). Pulmonary embolism in Nigeria. J. Nig. med. Ass., 4, 45.

Okuwobi, B. O. (1967). Pattern of heart failure at Lagos University Teaching Hospital. W. Afr. med. J., 16, 198.

Olazábal, F., Román-Irizarry, L., Oms, J. D., Conde, L., and Marchand, E. J. (1968). Pulmonary emboli masquerading as asthma. New Engl. J. Med., 278, 999.

Phillips, J. H., and Burch, G. E. (1960). A review of cardiovascular diseases in the white and Negro races. Medicine (Baltimore) 39, 241.

Stuart, K. L., and Hayes, J. A. (1963). A cardiac disorder of unknown aetiology in Jamaica. Quart. J. Med., 32, 99.

Woodruff, A. W. (1961). In Recent Advances in Tropical Medicine, 3rd. ed., ed. N. H. Fairley, A. W. Woodruff, and J. H. Walters. p. 421, Churchill, London.

World Health Organization (1961). Chronic cor pulmonale. Wld Hlth Org. techn. Rep. Ser. No. 213, Geneva. 